$\xi=$

\title{
Comparative safety profiles of two enrofloxacin generics after repeated intracrop administration to broilers
}

\author{
Nasser Ehmeza ${ }^{1}$, Abdelrazzag Elmajdoub ${ }^{1}$, Abdurazzag Abusnina ${ }^{1}$, \\ Emad Bennour ${ }^{2}$, Giuma Elhafi ${ }^{3}$, Abubakr El-Mahmoudy ${ }^{4}$ \\ ${ }^{1}$ Department of Pharmacology, Toxicology \& Forensic Medicine, Faculty of Veterinary Medicine, University of Tripoli, Tripoli, Libya \\ ${ }^{2}$ Department of Internal Medicine, Faculty of Veterinary Medicine, University of Tripoli, Tripoli, Libya \\ ${ }^{3}$ Department of Clinical Studies, Faculty of Agriculture and Veterinary Medicine, Azzaytuna University, Tarhuna, Libya \\ ${ }^{4}$ Department of Pharmacology, Faculty of Veterinary Medicine, Benha University, 13736 Moshtohor, Egypt \\ *Corresponding author E-mail: a.elmahmoudy@fvtm.bu.edu.eg
}

\begin{abstract}
Clinicochemical, haematological and histopathological alterations were demonstrated in broiler chickens following repeated oral bolus administration of two different enrofloxacin generic preparations, formulated as $10 \%$ oral solutions, given at a dose regimen of $10 \mathrm{mg} / \mathrm{Kg}$ body weight for 5 consecutive days. The two tested preparations were Enrol ${ }^{\circledR}$ (Medmac ${ }^{\circledR}$, Jordan), referred thereafter as ENRO-A; and Syvaquinol $^{\circledR}$ (Syva ${ }^{\circledR}$, Spain), which referred thereafter as ENRO-B. Eighteen broilers chickens, aging 40 days old, divided equally and randomly into three groups, have been used in the present study. ENRO-A or ENRO-B was given via intra-crop route of administration at the above-mentioned dose regimen to birds of the $2^{\text {nd }}$ and the $3^{\text {rd }}$ groups, respectively; where those of the $1^{\text {st }}$ group were given water instead and kept as control. Blood samples were collected from all birds via the wing and metatarsal veins on the $5^{\text {th }}$ day for clinicochemical and haematological examinations. Birds were then humanely sacrificed and liver, kidneys and heart were dissected out for histopathological examination. Results revealed that ENRO-A induced a significant $(p<0.05)$ increase of the activity of alkaline phosphatase compared to ENRO-B as well as control group. Both ENRO-A and ENRO-B caused significant increases in the levels of plasma urea and creatinine concentrations compared to control $(p<0.05)$, with higher significance in case of ENRO-A. Activity of plasma creatine kinase significantly $(p<0.05)$ increased after ENRO-A compared to control and ENRO-B-treated groups. ENRO-A and ENRO-B significantly $(p<0.05)$ increased blood glucose and triglyceride levels compared to that of control. Cholesterol level was increased significantly $(p<0.05)$ only after ENRO-B repeated administration. However, other metabolic parameters showed insignificant changes. Parallel inflammatory and degenerative histopathological changes in the affected organs, except kidneys, have been observed. Nevertheless, administration of either ENRO-A or ENRO-B caused insignificant changes in hematological parameters of the treated chicken groups. Data of the present study may indicate that enrofloxacin may cause organ dysfunction in broilers during the course of therapy based on clinicochemical and histopathological reasons. The data may also indicate that the pharmaceutical technology may be a detrimental factor in safety profiles of generic products based on the differences recorded between the two tested brands.
\end{abstract}

Keywords: Broiler Chicken; Enrofloxacin; Pharmacovigilance; Safety.

\section{Introduction}

Generic drug preparations became abundant nowadays from different sources with different efficacies, safety profiles and prices. However, not all preparations give the same desired effects and safety levels in the veterinary medical field. The term 'generic product' used by the World Health Organization (WHO) for a pharmaceutical product that is: i) intended to be interchangeable with the innovator product in an individual patient, ii) usually manufactured without a licence from the innovator company, and iii) marketed after expiry of patent or other exclusivity rights (Birkett 2003). Comparative clinical pharmacology studies are conducted by pharmacologists for the comparison of different medicinal products containing the same active substance.

Enrofloxacin (ENRO) is a synthetic chemotherapeutic agent, belonging to the second generation of the fluoroquinolone class, a derivative of quinolonecarboxylic acid group, used as antibacterial to combat infections. ENRO has a broad spectrum bactericidal activity against Gram-positive and Gram-negative bacteria (Merk
Index 2001). ENRO was developed exclusively for veterinary use in many animal species including, cattle, pigs, dogs, cats... etc. (Altreuther 1987); and for the treatment of respiratory disease in chickens and turkeys (Anderson et al. 2003). After administration, ENRO is partly de-ethylated to ciprofloxacin in vivo, which is also pharmacologically active and is employed in human medicine (Rao et al. 2002).

Although FDA withdrew the approval for ENRO for the purpose of treating bacterial infections in poultry because of scientific data that showed that the use of ENRO in poultry caused resistance to Campylobacter, a bacterium that causes foodborne illness (FDA 2005). However, in many developing countries, ENRO is being used as the routine choice to treat almost any bacterial disease in poultry.

Like all members of fluoroquinolones, ENRO produces its antimicrobial action in multiple species of bacteria via damage of bacterial DNA leading to defects in negative supercoiling. This effect was linked to inhibition of DNA gyrase activity, an enzyme found in all bacteria (Gellert et al. 1977). 
The original preparation of ENRO was produced by Bayer ${ }^{\circledR}$ Corporation, Animal Health Division (Barmen, Germany) under the trade name of Baytril ${ }^{\circledR}$ of different pharmaceutical formulations. However, nowadays, there are many generic preparations of ENRO marketed in the veterinary medical drug markets and not all preparations give the same desired effects and safety levels.

As the potential non-equivalence of a drug preparation has been a matter of pharmacological concern, therefore, the aim of the present study was to compare between the safety profiles of two ENRO preparations (ENRO-A and ENRO-B) that are widely distributed in the veterinary drug market for broiler industry after repeated intracrop (i.c.) administration; and giving recommendations to the concerned veterinary authorities, veterinarians and farmers about the elected brand from the pharmacovigilance point of view.

\section{Materials and methods}

\subsection{Drugs}

ENRO occurs as a pale yellow crystalline powder slightly soluble in water at $\mathrm{pH}=7$, soluble in potassium hydroxide, glacial acetic acid, ethanol, $0.1 \mathrm{M}$ hydrochloric acid, $0.1 \mathrm{M}$ sodium hydroxide (Heitzman 1997). ENRO has the following structural formula (Figure 1) and specifications:

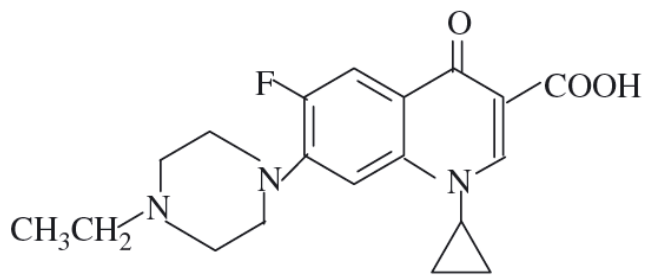

Fig. 1: Structural Formula of Enrofloxacin.

ENRO has the molecular formula $\mathrm{C}_{19} \mathrm{H}_{22} \mathrm{FN}_{3} \mathrm{O}_{3}$, the chemical Name: 1-cyclopropyl-7-(4-ethyl-1-piprazinyl)-6-fluoro-1,4dihydro-4-oxo-3-quinoline carboxylic acid; and molecular weight: $359.39 \mathrm{~g} / \mathrm{mole}$. Two generic ENRO oral preparations were used in the present study. They were obtained from our local drug market as $10 \%$ solutions. Brand-A was Enrol ${ }^{\circledR} 10$ oral solution, which contains ENRO at concentration of $100 \mathrm{mg} / \mathrm{ml}$; the preparation is a product of Medmac ${ }^{\circledR}$ (Amman, Jordan), Batch: v120804. While Brand-B was Syvaquinol ${ }^{\circledR} 10 \%$ oral solution, which also contains ENRO at concentration of $100 \mathrm{mg} / \mathrm{ml}$; the preparation is a product of Syva ${ }^{\circledR}$ (Leon, Spain); Batch: 301216.

\subsection{Experimental animals}

Eighteen clinically healthy Ross broiler chickens were used. Animals were numbered and accommodated in a suitable pen under hygienic condition with controlled temperature $\left(22 \pm 1^{\circ} \mathrm{C}\right)$, humidity $(60 \pm 10 \%)$ and light (12 h per day) for at least a week before being used. Food and water were available ad libitum. Feed was withdrawn 12 hours before drug administration to avoid absorption variability due to possible ENRO-feed interaction. Water was withdrawn 2 hour to minimize variation in stomach empting or degree of ENRO. The chickens were weighed prior to experiment for dose adjustment; the average body weight was $2.5 \mathrm{Kg}$.

The experiment was designed in a parallel manner where the chickens were grouped randomly into three groups; Group (I): included 6 chickens; each bird was orally (i.c.) administered repeated doses of distilled water for 5 consecutive days; and kept as control; Group (II): included 6 chickens; each bird was orally (i.c.) administered repeated doses of $10 \mathrm{mg} / \mathrm{kg}$ body weight of ENRO $10 \%$ (Brand-A) for 5 consecutive days; and Group (III): included 6 chickens; each bird was orally (i.c.) administered repeated doses of $10 \mathrm{mg} / \mathrm{kg}$ body weight of ENRO $10 \%$ (Brand-B) for 5 consecutive days.

\subsection{Drug preparation and administration}

The recommended dose of ENRO in poultry is $10 \mathrm{mg} / \mathrm{kg}$ body weight by various routes of administration. Each of the two commercial oral preparations was already formulated as ENRO $10 \%$ $(100 \mathrm{mg} / \mathrm{ml})$. Experimentally, an oral solution of ENRO $1 \%(10$ $\mathrm{mg} / \mathrm{ml}$ ) of both preparations (A) and (B) was prepared by adding $1.0 \mathrm{ml}$ of the corresponding stock solution of ENRO $10 \%$ to 9.0 $\mathrm{ml}$ of bi-distilled water. Administration via oral route was performed using a syringe with plastic cannula to deliver the drug solution i.c.

\subsection{Sampling}

On the fifth day, two hours post last dose, three $\mathrm{ml}$ of blood were drawn from each bird in into heparinized tubes properly labelled with group and chicken numbers. Each sample was divided into 2 parts; the first part was kept a whole blood that was used for hematology; while the second part was centrifuged at $3000 \mathrm{rpm}$ for 10 minutes to separate plasma for biochemical investigations. After blood collection, the chickens of each group were ethically sacrificed and specimens from liver, kidneys and heart were picked out for histopathological examination.

\subsection{Assays}

\subsubsection{Haematological assay}

To assess the blood safety profile of examined brands of ENRO (A \& B) in broilers, the following haematological parameters in control and treated $(10 \mathrm{mg} / \mathrm{kg}$ daily for 5 consecutive days, i.c.) chicken samples were automatically evaluated by autohaematology analyser (Mindray ${ }^{\circledR}$, Model BC-2800Vet, Shenzhen, China). Erythrocytic parameters included red blood cell (RBC) count, haematocrit value (HCT), mean corpuscular volume (MCV), haemoglobin concentration (HGB), mean corpuscular haemoglobin $(\mathrm{MCH})$ and mean corpuscular haemoglobin concentration (MCHC). Leukocytic parameters included white blood cell (WBC) count, differential leukocyte count (neutrophils, lymphocytes, monocytes, eosinophils, and basophils), platelets' (PLT) concentration, platelet distribution width (PDW), and mean platelet volume (MPV).

Usually in blood specimens, the cells are too close to each other to be identified or measured. For this reason, the special provided diluent was used to separate the cells so that they are drawn through the aperture of the auto-analyser one at a time as well as to create a conductive environment for blood analysis. When analysing a whole blood sample, the analyser aspirates $13 \mu \mathrm{L}$ of the sample and dilutes it (1: 308 for WBCs and 1: 44862 for RBCs) before proceeding to the actual analysis. After reacting with the diluent and lyse, the cells mainly fall into the following three volume ranges: WBC, 30 350 fL; RBC: $25 \sim 250 \mathrm{fL}$; PLT: $2 \sim 30$ $\mathrm{fL}$. With the help of the diluent and lysis buffer, the analyser can size the white cells into three sub-populations, lymphocytes, midsized cells, and granulocytes. The analyser adopts the Coulter Principle to count RBC, WBC, and PLT cells and to draw their corresponding histograms. The HGB concentration is obtained by the colorimetric method while the MCV and MPV are calculated electronically. The rest of indices are mathematically derived from those according to the following equations:

$$
\begin{aligned}
& \operatorname{HCT}(\%)=\frac{\operatorname{RBC}\left(10^{12} / \mathrm{L}\right) \times \operatorname{MCV}(\mathrm{fL})}{10} \\
& \operatorname{MCH}(p g)=\frac{\operatorname{HGB}(g / d L)}{\operatorname{RBC}\left(10^{12} / \mathrm{L}\right)} \times 10 \\
& \operatorname{MCHC}(g / d L)=\frac{\mathrm{HGB}(g / d L)}{\mathrm{HCT}(\%)} \times 100
\end{aligned}
$$

Based on the WBC histogram, this analyser calculates Lymph\%, $\mathrm{Mid} \%$ and $\mathrm{Gran} \%$ as follows: 


$$
\begin{aligned}
& \text { Lymph }(\%)=\frac{P L}{P L+P M+P G} \times 100 \\
& \text { Mid }(\%)=\frac{P M}{P L+P M+P G} \times 100 \\
& \text { Gran }(\%)=\frac{P G}{P L+P M+P G} \times 100
\end{aligned}
$$

Where, $\mathrm{PL}=$ particles in the lymphocyte region $\left(10^{9} / \mathrm{L}\right) ; \mathrm{PM}=$ particles in the mid-size region $\left(10^{9} / \mathrm{L}\right) ; \mathrm{PG}=$ particles in the granulocyte region $\left(10^{9} / \mathrm{L}\right)$.

$$
\begin{aligned}
& \operatorname{Lymph} \#\left(10^{9} / \mathrm{L}\right)=\frac{\operatorname{Lymph}(\%) \times \operatorname{WBC}\left(10^{9} / \mathrm{L}\right)}{100} \\
& \operatorname{Mid} \#\left(10^{9} / \mathrm{L}\right)=\frac{\operatorname{Mid}(\%) \times \operatorname{WBC}\left(10^{9} / \mathrm{L}\right)}{100} \\
& \operatorname{Gran\# }\left(10^{9} / \mathrm{L}\right)=\frac{\operatorname{Gran}(\%) \times \operatorname{WBC}\left(10^{9} / \mathrm{L}\right)}{100}
\end{aligned}
$$

PLT count $\left(10^{9} / \mathrm{L}\right)$ is measured directly by counting the platelets passing through the aperture; and based on the PLT histogram; the analyser electronically calculates the mean platelet volume (MPV, fL) and platelet distribution width (PDW). PCT is derived from the following equation:

$$
\operatorname{PCT}(\%)=\frac{\operatorname{PLT}\left(10^{9} / \mathrm{L}\right) \times \mathrm{MPV}(\mathrm{fL})}{10}
$$

\subsubsection{Clinico-chemical assays}

Estimating plasma clinicochemical parameters, evaluating hepatotoxicity, nephrotoxicity, cardiotoxicity and/or metabotoxicity was carried out spectrophotometrically (Jenway®, Model 6500, Germany) using diagnostic kits purchased from Analyticon ${ }^{\circledR}$ Biotechnologies AG (Lichtenfels, Germany). The parameters were alkaline phosphatase (Bessey et al. 1946), aspartate aminotransferase (Bergmeyer et al. 1986), alanine aminotransferase (Bergmeyer et al. 1986), total protein (Tietz 1995), creatine kinase (Black et al 1986), albumin (Marshall 1988), urea (Krieg et al. 1986), creatinine (Bartels et al. 1972), glucose (Schmidt 1961), and total cholesterol (Allain et al. 1974). Plasma triacylglycerols level was estimated using a diagnostic kit purchased from Biolabo ${ }^{\circledR}$ SA (Maizy, France) according to Fossati and Prencipe (1982). Globulin level was calculated by subtracting the value of albumin from the value of total protein according to Doumas and Biggs (1972).

\subsubsection{Histopathological assay}

The liver, heart and the two kidneys were taken from sacrificed birds in all groups and preserved in neutral formalin solution $10 \%$ and subjected for histopathological examination according to Bancroft and Gamble (2008). After 24 hours of fixation, samples were washed by running water over night. The washed samples were dehydrated by using graded increased concentrations of ethyl alcohol starting with $70 \%$ and ending with absolute alcohol. The dehydrated samples were immersed in xylol for 3 hours till clearance and then embedded in melted paraffin wax that was left to solidify after tissue immersion. Thin sections $(4-6 \mu \mathrm{m})$ were prepared from the solidified paraffin blocks by a rotative microtome (Leica ${ }^{\circledR}$, Germany).

For staining, paraffin was removed from the sections by two changes of absolute alcohol (five minutes in each) which was removed by washing with tap water. Sections were stained with Harris haematoxylin and eosin for 10 minutes, and then washed with running water for 15 minutes. Stained samples were then dehydrated by different concentrations of alcohol, and then immersed in xylol for clearance and covered by DBX. The obtained slides were subjected for routine microscopical examination.

\subsection{Statistical analysis}

Data were expressed as mean \pm standard error of the mean of 6 observations (n). Differences between control and treated groups were tested for significance using a one-way analysis of variance (ANOVA) followed by LSD as post-hoc test. P-values of 0.05 or less were considered significant. All statistical analytical procedures were done using SPSS software v.20 (Chicago, Illinois).

\section{Results}

Haematological, clinicochemical, and histopathological alterations were demonstrated in broiler chickens following repeated oral bolus administration of ENRO-A or ENRO-B at a dose rate of 10 $\mathrm{mg} / \mathrm{Kg}$ body weight for 5 consecutive days. All data are expressed as Mean \pm SEM of 6 chickens and differences between ENROtreated groups and corresponding control were determined using ANOVA followed by LSD as a post-hoc test; significance level was set at $\mathrm{P}<0.05$.

\subsection{Haemogram}

Oral administration of either ENRO-A or ENRO-B caused insignificant changes in hematological parameters as presented in tables $(1 \& 2)$.

\subsection{Clinico-chemical findings}

Table 3 shows the effect of ENRO-A and ENRO-B $(10 \mathrm{mg} / \mathrm{Kg}$; intracrop; for 5 consecutive days) on organ (liver, kidney \& heart) function profiles of broiler chickens compared to control (received only saline). Repeated oral administration of ENRO-A induced a significant $(\mathrm{P}<0.05)$ increase of the activity of alkaline phosphatase compared to ENRO-B as well as control group. Both ENRO$A$ and ENRO-B caused significant increase in levels of plasma urea and creatinine concentrations compared to control $(\mathrm{P}<0.05)$, with higher significance in case of ENRO-A. Activity of plasma creatine kinase significantly $(\mathrm{P}<0.05)$ increased after ENRO-A compared to control group and ENRO-B-treated group as well.

Table 1: Comparative Effects of Oral Administration of $10 \mathrm{mg} / \mathrm{Kg}$ Body Weight Per Day for 5 Consecutive Days of ENRO-A and ENRO-B on the Leukocytic Parameters in Broiler Chickens (Mean $\pm \mathrm{SE} ; \mathrm{N}=6$ ).

\begin{tabular}{llll}
\hline & Control & ENRO-A & ENRO-B \\
\hline $\begin{array}{l}\text { WBCs }\left(x 10^{9} / \mathrm{L}\right) \\
\begin{array}{l}\text { Granulocytes } \\
\left(\mathrm{x} 10^{9} / \mathrm{L}\right)\end{array}\end{array}$ & $20.340 \pm 1.90$ & $20.298 \pm 2.97$ & $20.14 \pm 2.22$ \\
$\begin{array}{l}\text { Monocytes } \\
\left(\mathrm{x} 10^{9} / \mathrm{L}\right)\end{array}$ & $3.530 \pm 0.700$ & $3.450 \pm 1.250$ & $3.35 \pm 0.890$ \\
$\begin{array}{l}\text { Lymphocytes } \\
\left(\mathrm{x} 10^{9} / \mathrm{L}\right)\end{array}$ & $4.265 \pm 0.949$ & $4.660 \pm 0.712$ & $4.38 \pm 0.651$ \\
$\begin{array}{l}\text { PLT } \\
\left(\mathrm{x} 10^{9} / \mathrm{L}\right)\end{array}$ & $78.08 \pm 7.700$ & $77.80 \pm 13.80$ & $78.8 \pm 3.40$ \\
MPV (fL) & $5.720 \pm 0.150$ & $5.830 \pm 0.280$ & $5.92 \pm 0.13$ \\
PDW $(\%)$ & $14.98 \pm 0.100$ & $14.88 \pm 0.120$ & $15.5 \pm 0.17^{\mathrm{a}, \mathrm{b}}$ \\
PCT $(\%)$ & $0.043 \pm 0.004$ & $0.039 \pm 0.009$ & $0.041 \pm 0.003$ \\
\hline
\end{tabular}

$\mathrm{a}, \mathrm{b}$ and $\mathrm{c}$ mean significantly different from control, ENRO-A and ENRO$\mathrm{B}$, respectively; $(\mathrm{P}<0.05)$.

Table 2: Comparative Effects of Oral Administration of $10 \mathrm{mg} / \mathrm{Kg}$ Body Weight Per Day for 5 Consecutive Days of ENRO-A and ENRO-B on the Erythrocytic Parameters in Broiler Chickens (Mean $\pm \mathrm{SE}$; $=6$ ).

\begin{tabular}{llll}
\hline & Control & ENRO-A & ENRO-B \\
\hline RBCs $\left(x 10^{12} / \mathrm{L}\right)$ & $2.600 \pm 0.07$ & $2.500 \pm 0.08$ & $2.700 \pm 0.14$ \\
HBG $(\mathrm{g} / \mathrm{dL})$ & $14.75 \pm 0.50$ & $14.10 \pm 0.60$ & $13.95 \pm 0.40$ \\
HCT $(\%)$ & $31.80 \pm 0.90$ & $29.80 \pm 1.30$ & $30.50 \pm 1.40$ \\
MCV (fL) & $119.2 \pm 1.50$ & $117.9 \pm 1.60$ & $115.3 \pm 2.00$ \\
MCH $(\mathrm{pg})$ & $54.90 \pm 1.40$ & $55.80 \pm 1.20$ & $53.05 \pm 2.65$ \\
MCHC (g/dL) & $46.10 \pm 0.65$ & $48.10 \pm 0.99$ & $45.98 \pm 1.67$ \\
RDW $(\%)$ & $8.300 \pm 0.40$ & $7.800 \pm 0.30$ & $8.500 \pm 0.60$ \\
\hline
\end{tabular}

$\mathrm{a}, \mathrm{b}$ and $\mathrm{c}$ mean significantly different from control, ENRO-A and ENRO$\mathrm{B}$, respectively; $(\mathrm{P}<0.05)$. 
As shown in table 4, ENRO-A and ENRO-B significantly $(\mathrm{P}<0.05)$ increased blood glucose and triglyceride levels compared to that of control. Cholesterol level was increased significantly $(\mathrm{P}<0.05)$ only after ENRO-B repeated administration. However, other metabolic parameters showed insignificant changes.

Table 3: Comparative Effects of Oral Administration of $10 \mathrm{mg} / \mathrm{Kg}$ Body Weight Per Day for 5 Consecutive Days of ENRO-A and ENRO-B on Selected Biochemical Parameters Related to Liver, Heart and Kidney Functions in Broiler Chickens (Mean $\pm \mathrm{SE} ; \mathrm{N}=6$ )

\begin{tabular}{lllllll}
\hline & $\begin{array}{l}\text { ALT } \\
(\mathrm{IU} / \mathrm{L})\end{array}$ & $\begin{array}{l}\text { ALP } \\
(\mathrm{IU} / \mathrm{L})\end{array}$ & $\begin{array}{l}\text { AST } \\
(\mathrm{IU} / \mathrm{L})\end{array}$ & $\begin{array}{l}\text { CK } \\
(\mathrm{IU} / \mathrm{L})\end{array}$ & $\begin{array}{l}\text { Creatinine } \\
(\mathrm{mg} / \mathrm{dL})\end{array}$ & $\begin{array}{l}\text { Urea } \\
(\mathrm{mg} / \mathrm{dL})\end{array}$ \\
\hline & 34.56 & 588.05 & 166.2 & 112.65 & 0.61 & 14.48 \\
Control & \pm & \pm & \pm & \pm & \pm & \pm \\
& 6.76 & $67.63^{\mathrm{b}}$ & 11.2 & $12.4^{\mathrm{b}}$ & $0.045^{\mathrm{b}, \mathrm{c}}$ & $0.36^{\mathrm{b}, \mathrm{c}}$ \\
& 45.23 & 930.15 & 187.25 & 336.25 & 0.90 & 26.6 \\
ENRO- & \pm & \pm & \pm & \pm & \pm & \pm \\
$\mathrm{A}$ & 7.8 & $75.3^{\mathrm{a}, \mathrm{c}}$ & 13.3 & $26.9^{\mathrm{a}, \mathrm{c}}$ & $0.041^{\mathrm{a}}$ & $0.40^{\mathrm{a}}$ \\
& 40.53 & 665.45 & 176.75 & 185.35 & 0.85 & 23.40 \\
ENRO- & \pm & \pm & \pm & \pm & \pm & \pm \\
B & 6.33 & $55.65^{\mathrm{b}}$ & 18.7 & 15.55 & $0.050^{\mathrm{a}}$ & $0.26^{\mathrm{a}}$ \\
\hline
\end{tabular}

$\mathrm{a}, \mathrm{b}$ and $\mathrm{c}$ mean significantly different from control, ENRO-A and ENRO$\mathrm{B}$, respectively; $(\mathrm{P}<0.05)$

\subsection{Histopathological findings}

Table There were no histopathological alterations and normal histological structures of the central and portal veins with surrounding hepatocytes were recorded in the liver of control group (Fig. 2 \& 3). Oral administration of enrofloxacin 10\% (Brand A) daily at a dose of $10 \mathrm{mg} / \mathrm{kg}$ body weight for five consecutive caused moderate focal lymphoid cells aggregation was observed in the hepatic parenchyma (Fig. 4) and dilatation in the portal vein associated with inflammatory cells infiltration mainly lymphocytes in the portal area (Fig. 5) while in ENRO-B, dilatation of the central vein was noticed (Fig. 6); and the hepatic parenchyma showed severe focal aggregation of the lymphoid cells (Fig. 7).

Table 4: Comparative Effects of Oral Administration of $10 \mathrm{mg} / \mathrm{Kg}$ Body Weight Per Day for 5 Consecutive Days of ENRO-A and ENRO-B on Selected Biochemical Parameters Related to Metabolism in Broiler Chickens (Mean $\pm \mathrm{SE} ; \mathrm{N}=6$ ).

\begin{tabular}{lllllll}
\hline & $\begin{array}{l}\text { TP } \\
(\mathrm{mg} / \mathrm{dL}\end{array}$ & $\begin{array}{l}\text { AL } \\
(\mathrm{mg} / \mathrm{dL}\end{array}$ & $\begin{array}{l}\text { GLs } \\
(\mathrm{mg} / \mathrm{dL}\end{array}$ & $\begin{array}{l}\text { TAGs } \\
(\mathrm{mg} / \mathrm{dL}\end{array}$ & $\begin{array}{l}\text { Choles- } \\
\text { terol } \\
(\mathrm{mg} / \mathrm{dL})\end{array}$ & $\begin{array}{l}\text { Glu- } \\
\text { cose } \\
(\mathrm{mg} / \mathrm{dL}\end{array}$ \\
& ) & ) & ) & ) & & \\
\hline Con- & 4.88 & 1.82 & 2.81 & 82.46 & 91.08 & 218.55 \\
trol & \pm & \pm & \pm & \pm & \pm & \pm \\
& 0.22 & 0.07 & 0.20 & 4.90 & 7.95 & 7.14 \\
EN- & 4.75 & 1.73 & 2.85 & 98.59 & 103.99 & 247.2 \\
RO- A & \pm & \pm & \pm & \pm & \pm & \pm \\
& 0.21 & 0.10 & 0.11 & $5.06^{\mathrm{a}}$ & 13.20 & $9.3^{\mathrm{a}}$ \\
EN- & 4.82 & 1.81 & 2.98 & 106.90 & 125.08 & 257.25 \\
RO- B & \pm & \pm & \pm & \pm & \pm & \pm \\
& 0.98 & 0.05 & 0.10 & $7.32^{\mathrm{a}}$ & $12.80^{\mathrm{a}}$ & $10.5^{\mathrm{a}}$ \\
\hline
\end{tabular}

$\mathrm{a}, \mathrm{b}$ and $\mathrm{c}$ mean significantly different from control, ENRO-A and ENRO$\mathrm{B}$, respectively; $(\mathrm{P}<0.05)$

Kidneys dissected from control group, ENRO-A- or ENRO-Btreated groups showed no histopathological alterations and the normal histological structure of the glomeruli and tubules were recorded in figures $8,9 \& 10$, respectively.

Oral administration of ENRO-A caused mild focal inflammatory cells infiltration in between the myocardial bundles (Fig. 11) on the other hand, control and ENRO-B groups showed normal histological structure of the myocardial bundles (Figs. $13 \& 14$ ), respectively, with reference to control (Fig. 12).

\section{Discussion}

The $2^{\text {nd }}$ generation fluoroquinolones were developed in the $1980 \mathrm{~s}$ exhibited increased antibacterial activity against the Enterobacteriaceae and other Gram-negative bacteria (such as P. aeruginosa), and had some activity against certain Gram-positive cocci in addi- tion. Structural changes associated with the $2^{\text {nd }}$ generation, from the $1^{\text {st }}$ one, increased their oral bioavailability and systemic distribution. They include norfloxacin, ciprofloxacin, enrofloxacin, danofloxacin, difloxacin and marbofloxacin.

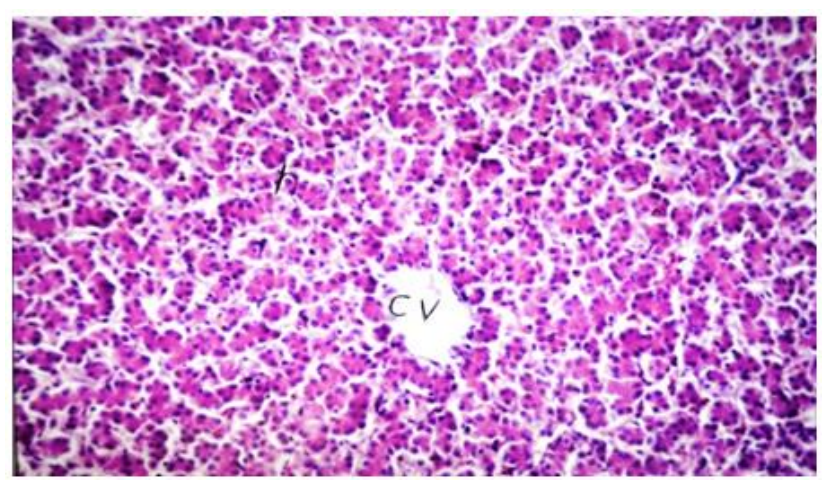

Fig. 2: Liver of a Bird Showing Normal Histological Structure of the Central Vein (CV) and the Surrounding Hepatocytes in the Parenchyma (H\&E, X40).

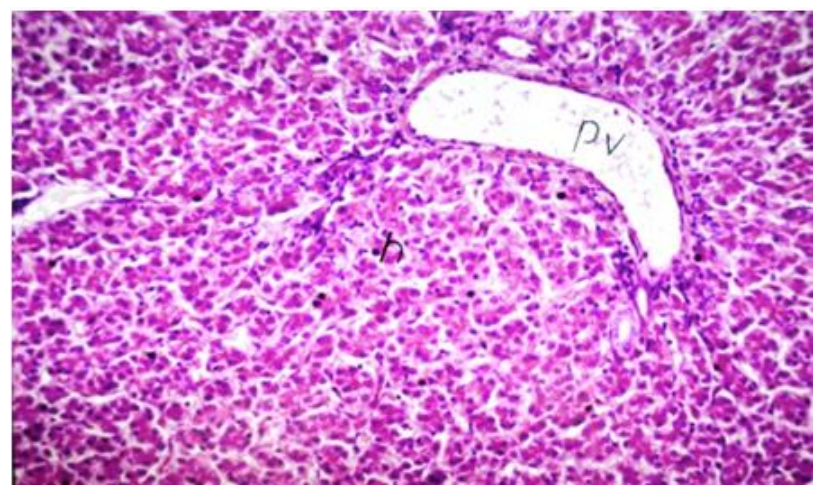

Fig. 3: Liver of a Bird Showing Normal Histological Structure of the Portal Vein (PV) in Portal Area and the Surrounding Hepatocytes in the Parenchyma (H\&E, X40).

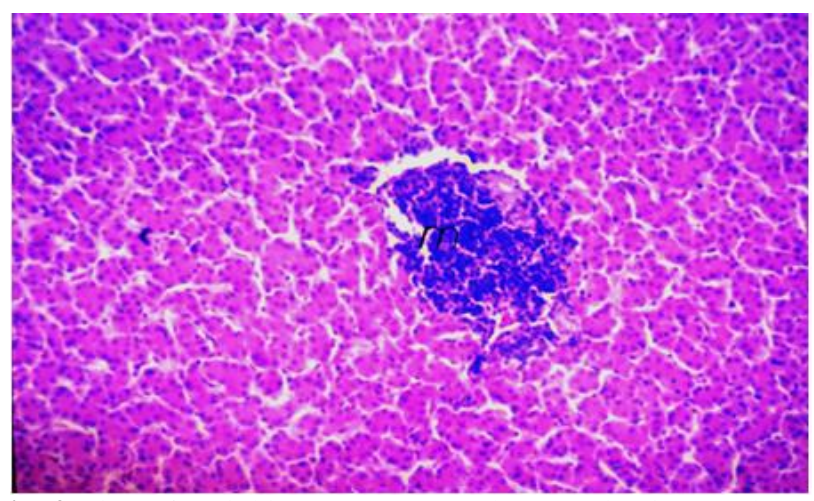

Fig. 4: Liver of a Bird in ENRO-A-Treated Group Showing Focal Lymphoid Cells Aggregation (M) in Hepatic Parenchyma (H\&E, X40).

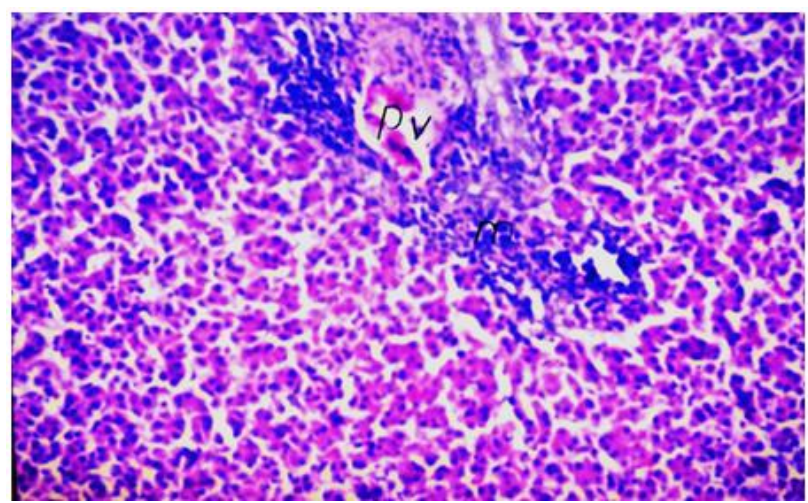

Fig. 5: Liver of a Bird in ENRO-A-Treated Group Showing Dilatation of the Portal Vein (PV) And Infiltration of Inflammatory Cells in Portal Area (M), (H\&E, X40) 


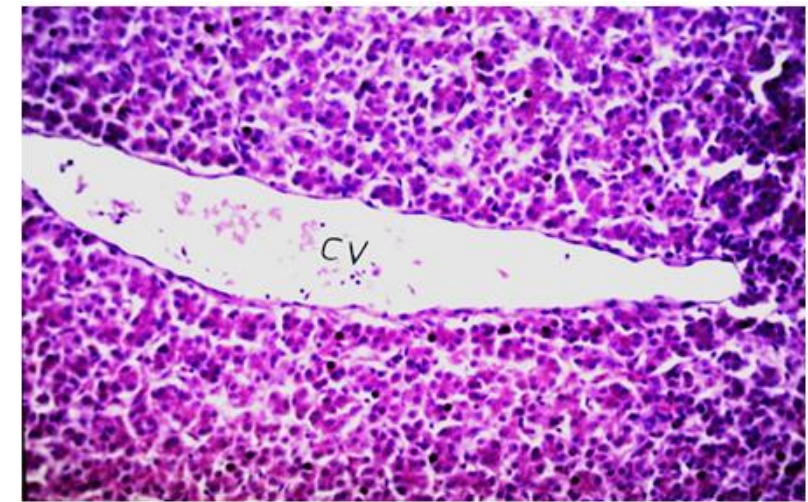

Fig. 6: Liver of a Bird in ENRO-B-Treated Showing Dilatation in Central Vein $(\mathrm{CV}),(\mathrm{H} \& \mathrm{E}, \mathrm{X} 40)$.

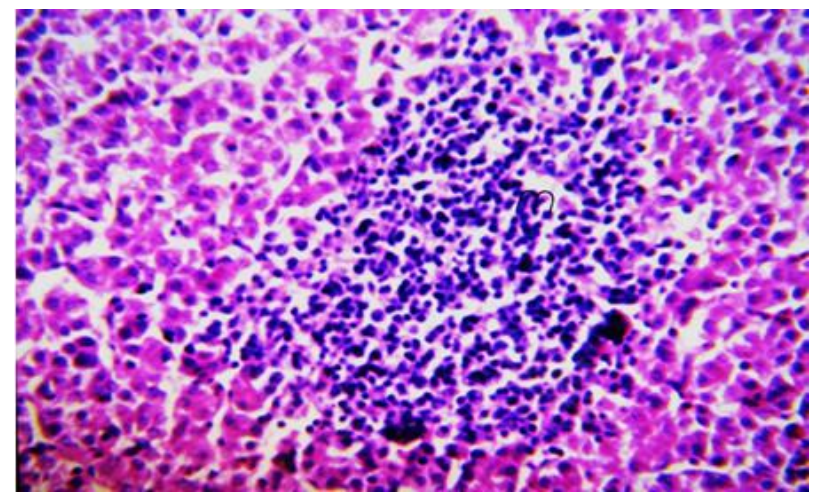

Fig. 7: Liver of a Bird in ENRO-B-Treated Showing Focal Lymphoid Cells Aggregation in Hepatic Parenchyma (M), (H\&E, X40).

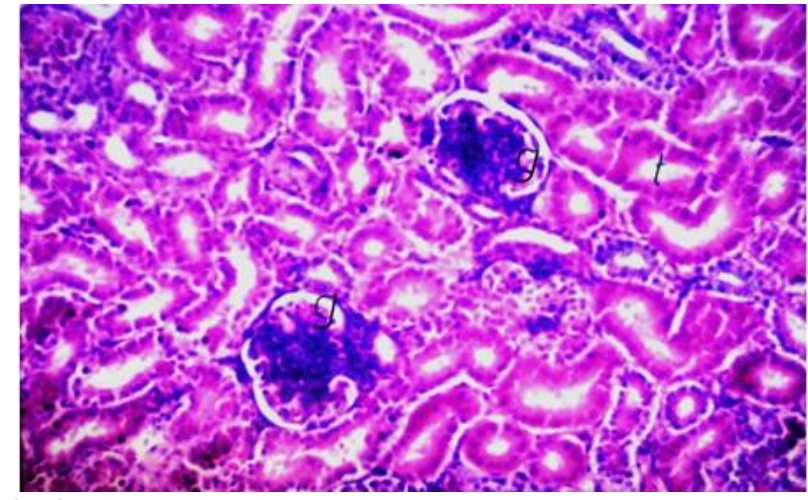

Fig. 8: Kidney of a Bird Showing Normal Histological Structure of the Glomeruli (G) and the Tubules (T), (H\&E, X40).

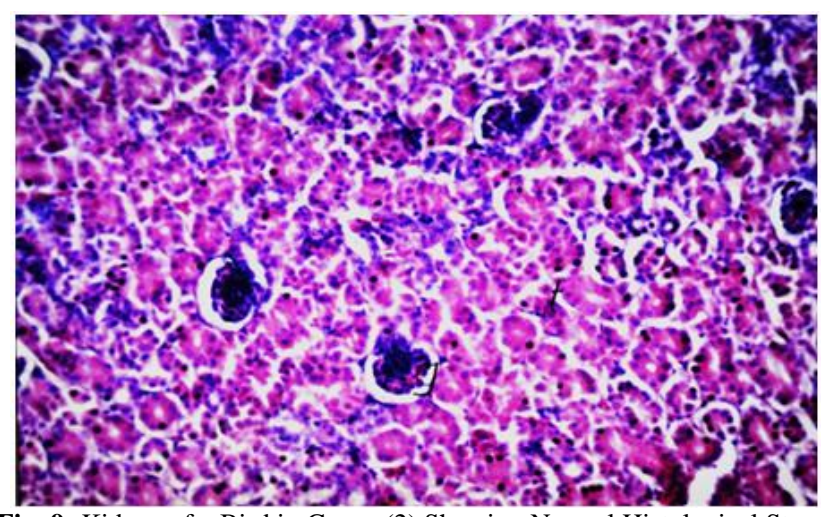

Fig. 9: Kidney of a Bird in Group (2) Showing Normal Histological Structure of Glomeruli $(\mathrm{G})$ and Tubules (T), (H\&E, X40).

Among these, enrofloxacin (Fig. 1) was developed exclusively for veterinary use in many animal species including, cattle, pigs, dogs, cats... etc. (Altreuther 1987); and for the treatment of respiratory disease in chickens and turkeys (Anderson et al. 2003).

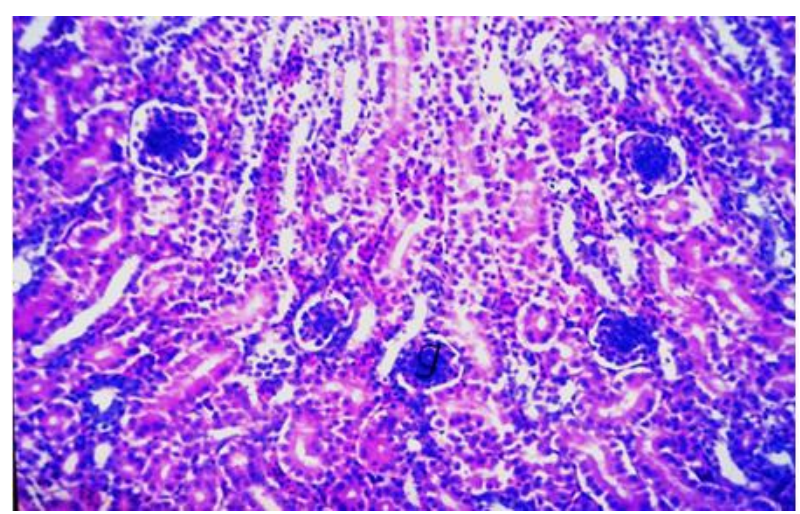

Fig. 10: Kidney of a Bird in Group (3) Showing Normal Histological Structure (H\&E, X40).

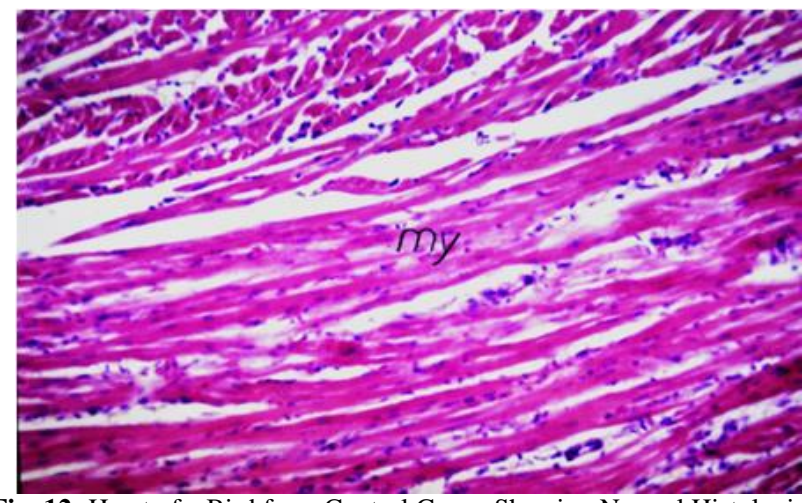

Fig. 12: Heart of a Bird from Control Group Showing Normal Histologica Structure of the Myocardial Bundles (My), (H\&E, X40).

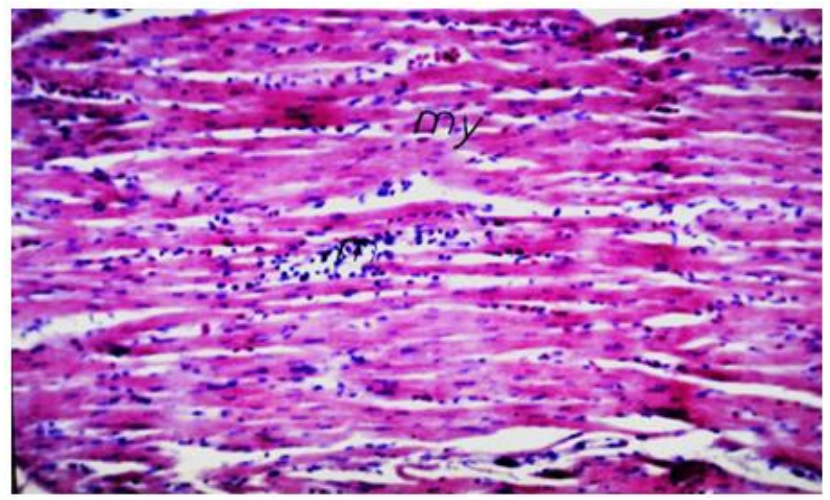

Fig. 13: Heart of a Bird in ENRO-A-Treated Group Showing Infiltration of Inflammatory Cells in Between Myocardial Bundles (M), (H\&E, X40).

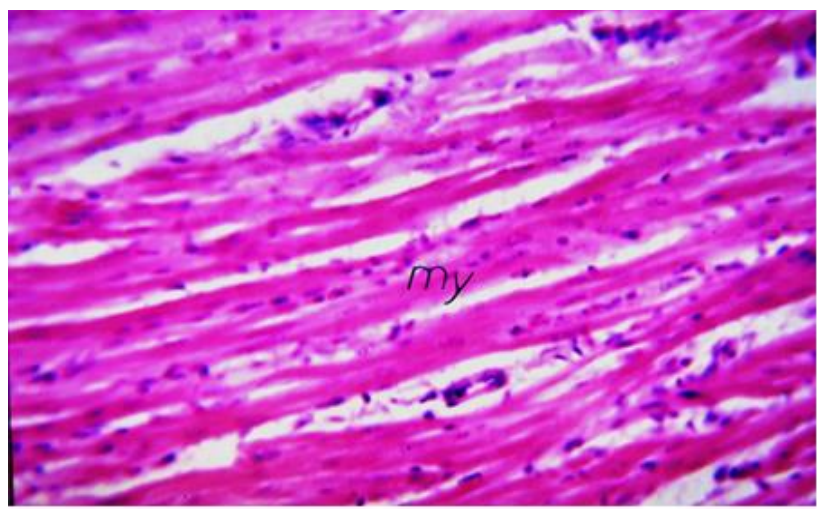

Fig. 14: Heart of a Bird in ENRO-B-Treated Group Showing Normal Histological Structure (H\&E, X40).

After administration, ENRO is partly de-ethylated to ciprofloxacin in vivo, which is also pharmacologically active and is employed in human medicine (Rao et al. 2002). The drug is being used in many developing countries as a routine choice to treat almost any bacte- 
rial disease in poultry, although its use has been banned in some advanced countries (Sumano et al. 2003).

Bioequivalence studies are generally recommended by FDA using the following endpoints: Pharmacokinetic endpoint; Pharmacodynamic endpoint; Clinical endpoint; and in vitro endpoint (Midha and McKay 2009). The authors evaluated the same tested ENRO brands from the pharmacokinetic endpoint in a previous study (Ehmeza et al. 2016). Here, the drug preparations were compared from the clinical point of view.

Estimation of plasma clinicochemical biomarkers, blood parameters and indices, as well as histopathological alterations may give a major picture about assessment of a drug safety. Liver and kidney, in particular, are target organs as they are the sites of drug metabolism and elimination. The heart function was also evaluated as the heart is a vital organ and could be affected by some drugs.

Repeated oral administration of ENRO-A induced a significant $(\mathrm{p}<0.05)$ increase of the activity of alkaline phosphatase compared to ENRO-B as well as control group (Table 3 ). While other hepatic biomarkers, ALT and AST remained insignificantly changed after ENRO-treatment.

Although ALP is formed mostly in the liver, yet, it is nonspecific to hepatic injury as it is formed by other tissues as bone, kidney, skeletal muscle and placenta. However, the degenerative changes in the liver tissue shown in figures $(4 \& 5)$ may give a support to the hypothesis of hepatic injury caused by ENRO-A administration. This adverse hepatic effect may be attributed to the enrofloxacin-induced reactive oxygen species generation as reported by Ibrahim and Yarsan (2009) and Sureshkumar et al. (2013b). The lesser changes recorded after ENRO-B administration (Figs. 6 \& 7) may be attributed to the difference in pharmaceutical technologies adopted in ENRO brands industries. Oral administration may be stressful on the liver more than injection because of the first pass effect. It is also worthy to note that ALP concentration in juvenile birds is significantly higher than that of adult birds as it is induced by increased cellular activity and synthesis rather than cell damage. In contrast to mammals, ALP of birds is also found at higher concentrations in duodenum and kidney (Clubb et al. 1990). This finding may be not in accordance with that of Sureshkumar et al. (2013a) who showed that administration of enrofloxacin $10 \%$ daily at a dose of $10 \mathrm{mg} / \mathrm{kg}$ body weight for 5 consecutive days via drinking water to broiler chickens induced insignificant increase in levels of ALP. This difference may be attributed to different research environment and different ENRO source.

Although histopathological examination did not reveal obvious pathological changes in the kidney tissues, both tested brands of ENRO caused significant increases in the levels of plasma urea and creatinine concentrations compared to control $(p<0.05)$, with higher significance in case of ENRO-A. Urea is formed in the liver and represents the principle end-product of protein catabolism. It is excreted almost entirely by the kidneys and about 25 to $40 \%$ of the filtered urea is reabsorbed. Thus, the recorded high value in the present study may refer to hyper-ammonaemia, rather than uremia, that resulted from the adversely affected liver; and/or reduced glomerular filtration rate. Creatinine is a specific indicator for evaluating kidney function as it is excreted only via this route. However, inability to record obvious pathological changes in the renal tissue may attribute the recorded high concentrations of creatinine to either the decreased glomerular filtration rate because of extra-renal cause; and/or muscular damage where creatinine is the metabolite of the muscular creatine phosphate. The obtained result may be inconsistent with Sureshkumar et al. (2013a) who reported that administration of enrofloxacin $10 \%$ daily at a dose of 10 $\mathrm{mg} / \mathrm{kg}$ body weight for 5 consecutive days via drinking water to broilers induced insignificant increase in the serum level of urea concentrations; but consistent with those of Küng et al. (1993) and Sureshkumar et al. (2013a) who reported significant increases in serum creatinine.

Creatine kinase (CK) is a dimeric enzyme occurring in four different forms: a mitochondrial isoenzyme and the cytosolic isoen- zymes CK-MM (muscle type), CK-BB (brain type) and CK-MB (myocardial type). The determination of $\mathrm{CK}$ and CK-isoenzyme activities is utilized in the diagnosis and monitoring of myocardial infarction and myopathies. Following injury to the myocardium, $\mathrm{CK}$ is released from the damaged myocardial cells. In early cases, a rise in the CK activity can be found just 4 hours after an injury, the CK-activities reaches a maximum after 12-24 hours and then falls back approximately to the normal range after 3-4 days. Elevated levels of $\mathrm{CK}$ reported in this study may indicate a possible mild damaging effect of ENRO-A, but not ENRO-B, on the myocardial cells of broilers that were treated repeatedly for 5 consecutive days. The result is parallel to the histopathological findings reported in the present study, where repeated oral administration of ENRO-A caused mild focal inflammatory cells infiltration in between the myocardial bundles (Fig. 13), but control and ENROB groups showed normal histological structure of the myocardial bundles (Figs. $12 \& 14$ ), respectively. The data may be partially consistent with that reported by Sureshkumar et al. (2013a) in chickens.

Glucose is the primary energy source for the animal body. It is derived from the breakdown of carbohydrates in diet and in body stores as well as by endogenous synthesis from protein or the glycerol moiety of triglycerides. Glucose level in blood is maintained within a fairly narrow range by regulatory hormones such as insulin, glucagon or epinephrine. Glucose is excreted in urine in minute undetectable amounts which in turn reabsorbed by renal tubules whatever it is within the normal range. As shown in table (4), both ENRO-A and ENRO-B significantly $(\mathrm{p}<0.05)$ increased blood glucose levels compared to that of control. This may be speculated as a result from the increased rate of glycogenolysis or gluconeogenesis by the liver and muscles and/or the decreased insulin secretion by the pancreatic islets. Glucose homeostasis at the recorded normal high levels in chickens remains as not yet understood physiological phenomenon. This finding may be not in accordance with that of Aziz (2005) who reported insignificant decline in levels of serum glucose in chicken treated with enrofloxacin $10 \%$ for 5 consecutive days via drinking water.

The present study showed that both ENRO brands at the given dose regimen to broilers caused significant increases in triglyceride levels. While, cholesterol significant increase was recorded after only ENRO-B administration. These abnormal changes in lipid parameters may follow hepatic dysfunction caused by ENRO repeated administration. This result may be inconsistent with the finding of Aziz (2005) who recorded insignificant decline in cholesterol level after enrofloxacin $10 \%$ oral solution administration.

Protein parameters did not show significant changes after both ENRO brands treatment in broiler chickens. The finding may be consistent with that of Küng et al. (1993) reported that administration of enrofloxacin $20 \%$ daily at a dose of $10 \mathrm{mg} / \mathrm{kg}$ body weight for 5 consecutive days was accompanied with insignificant decrease in total proteins and globulins.

Haematological profiles revealed significant increase in platelets distribution width (PDW) after oral administration of ENRO-B $10 \%$ solution daily at a dose of $10 \mathrm{mg} / \mathrm{kg}$ body weight for 5 consecutive compared with that of ENRO-A and control group $(\mathrm{p}<0.05)$. However, other hematological parameters did not show significant changes. A normal PDW indicates that platelets are mostly of the same size, while a high PDW means that platelet size varies greatly, a clue that there may be a disorder affecting platelets. A false result may be recorded by the virtue of clumping some platelets together in blood samples. Aziz (2005) stated that differences in hematological values between treated group with enrofloxacin $10 \%$ for 5 consecutive days via drinking water and corresponding control groups were not significant $(\mathrm{p}<0.05)$ giving almost accordance with our data. Ibrahim et al. (2011) found only significant increases in hemoglobin level and mean corpuscular hemoglobin $(\mathrm{MCH})$ values when enrofloxacin $10 \%$ was orally administered at a dose of $10 \mathrm{mg} / \mathrm{kg}$ body weight daily for 5 consecutive days to chickens compared with corresponding controls $(\mathrm{p}<0.05)$. However, other hematological parameters including RBCs, PCV, MCHC, MCV, WBCs and the differential leukocyte 
counts did not show any significant changes. With exception of $\mathrm{Hb}$ and $\mathrm{MCH}$, these findings are in accordance with the recorded ones in the present study and suggest that administration of enrofloxacin $10 \%$ daily at a dose of $10 \mathrm{mg} / \mathrm{kg}$ body weight for 5 consecutive days do not cause anemia.

\section{Conclusion}

From the safety endpoint, any of the tested brands, Enrol ${ }^{\circledR}$ or Syvaquinol ${ }^{\circledR}$ did not cause any clinical serious manifestations on the treated birds, yet laboratory analysis revealed some adverse effects on some organs as liver and heart as well as alterations in some clinicochemical parameters especially after ENRO-A brand. The recorded side effects are a common feature of almost all drugs and usually disappear after completing the course of drug therapy.

\section{Acknowledgements}

The authors would like to thank Prof. Dr. Sabry El-Khodery, Department of Animal Medicine, Mansoura University, Egypt, for kind help in blood analysis.

Thanks are also attributed to Prof. Dr. Adel Bakeer, Department of Pathology, Cairo University, Egypt, for performing histopathology.

\section{References}

[1] Allain CC, Poon LS, Chan CS, Richmond W \& Fu PC (1974), Enzymatic determination of total serum cholesterol. Clinical Chemistry 20, 470-475.

[2] Altreuther P (1987), [Data on chemistry and toxicology of Baytril] Veterinaer-Medizinische Nachrichten (Germany, FR).

[3] Anderson AD, Nelson JM, Rossiter S \& Angulo FJ (2003), Public health consequences of use of antimicrobial agents in food animals in the United States. Microbial Drug Resistance 9, 373-379. http://dx.doi.org/10.1089/107662903322762815.

[4] Aziz AA (2005), The influence of enrofloxacin on hematological features, total cholesterol, blood glucose and body weight of broilers. Alqadissyia Journal of Veterinary Science 4, 29-33.

[5] Bancroft JD \& Gamble M (2008), Theory and practice of histological techniques: Elsevier Health Sciences.

[6] Bartels H, Böhmer M \& Heierli C (1972), Serum creatinine determination without protein precipitation. Clinica chimica acta 37, 193. http://dx.doi.org/10.1016/0009-8981(72)90432-9.

[7] Bergmeyer H, Herder M \& Ref R (1986), International Federation of Clinical Chemistry (IFCC). J Clin Chem Clin Biochem 24, 497510.

[8] Bessey O, Oliver H \& Jane M (1946), A method for the rapid determination of alkaline phosphatase with five cubic millimeters of serum. Journal of Biological Chemistry 164, 321-329.

[9] Birkett DJ (2003), Generics-equal or not? Australian Prescriber 26 85-86. http://dx.doi.org/10.18773/austprescr.2003.063.

[10] Black HR, Quallich H \& Gareleck CB (1986), Racial differences in serum creatine kinase levels. The American Journal of Medicine 81, 479-487. http://dx.doi.org/10.1016/0002-9343(86)90303-7.

[11] Clubb SL, Schubot RM, Joyner K, Zinkl JG, Wolf S, Escobar J, Clubb KJ \& Kabbur MB (1990), Hematologic and serum biochemical reference intervals in juvenile eclectus parrots (Eclectus roratus). Journal of the Association of Avian Veterinarians 218-225. http://dx.doi.org/10.2307/27670971.

[12] Doumas BT \& Biggs HG (1972), Determination of serum globulins In: Cooper GR, editor. Standard Methods of Clinical Chemistry. New York, NY: Academic Press. p 175.

[13] Ehmeza N, Elmajdoub A \& El-Mahmoudy A (2016), Comparative pharmacokinetics and absolute bioavailabilities of two enrofloxacin generic preparations after single intracrop bolus administrations to broiler chickens. International Journal of Pharmacology and Toxicology 4, 115-122. http://dx.doi.org/10.14419/ijpt.v4i2.6248.

[14] FDA U (2005), Food and Drug Administration final decision of the Commissioner. Docket no. 2000n-1571. Withdrawal of approval of the new animal drug application for enrofloxacin in poultry. In.

[15] Fossati P \& Prencipe L (1982), Serum triglycerides determined colorimetrically with an enzyme that produces hydrogen peroxide. Clinical Chemistry 28, 2077-2080.
[16] Gellert M, Mizuuchi K, O'Dea MH, Itoh T \& Tomizawa J-I (1977), Nalidixic acid resistance: a second genetic character involved in DNA gyrase activity. Proceedings of the National Academy of Sciences 74, 4772-4776. http://dx.doi.org/10.1073/pnas.74.11.4772.

[17] Heitzman RJ (1997), Enrofloxacin In: Identity. Berkshire, United Kingdom. p 31-44.

[18] Ibrahim IG, Atmaca N, Kanici A \& Yarsan E (2011), Evaluation of effects of enrofloxacin on some haematological parameters in broilers. Atatürk Üniversitesi Veteriner Bilimleri Dergisi 6, 97-102.

[19] Ibrahim IG \& Yarsan E (2009), Pharmacokinetics of enrofloxacin in broiler chicks. Sudan Journal of Veterinary Research 24, 1-4

[20] Krieg M, Gunsser K, Steinhagen-Thiessen E \& Becker H (1986), Comparative quantitative clinico-chemical analysis of the characteristics of 24-hour urine and morning urine. Journal of clinical chemistry and clinical biochemistry Zeitschrift fur klinische Chemie und klinische Biochemie 24, 863-869.

[21] Küng K, RIOND JL \& Wanner M (1993), Pharmacokinetics of enrofloxacin and its metabolite ciprofloxacin after intravenous and oral administration of enrofloxacin in dogs. Journal of Veterinary Pharmacology and Therapeutics 16, 462-468. http://dx.doi.org/10.1111/j.1365-2885.1993.tb00212.x.

[22] Marshall W (1988), Plasma proteins. Illustrated textbook of clinical chemistry. In: londres: gower Medical Publishing.

[23] Merk Index (2001), Enrofloxacin, 13th ed. White house statio, New jersey, USA: Merk and company incorporation.

[24] Midha KK \& McKay G (2009), Bioequivalence; its history, practice, and future. The AAPS journal 11, 664-670. http://dx.doi.org/10.1208/s12248-009-9142-z.

[25] Rao G, Ramesh S, Ahmad A, Tripathi H, Sharma L \& Malik J (2002), Disposition kinetics of enrofloxacin and ciprofloxacin following intravenous administration of enrofloxacin in goats. Small Ruminant Research 44, 9-15. http://dx.doi.org/10.1016/S0921-4488(02)00003-2.

[26] Schmidt F (1961), Enzymatic determination of glucose and fructose simultaneously. Klinische Wochenschrift 39, 1244-1247. http://dx.doi.org/10.1007/BF01506150.

[27] Sumano L, Gutierrez O \& Zamora Q (2003), Strategic administration of enrofloxacin in poultry to achieve higher maximal serum concentrations. The Veterinary Journal 165, 143-148. http://dx.doi.org/10.1016/S1090-0233(02)00165-X.

[28] Sureshkumar V, Sarathchandra G \& Ramesh J (2013a), Biochemical, histopathological and ultra structural profile after pulsed water medication of enrofloxacin in broiler chickens. Veterinary World 6, 668-673. http://dx.doi.org/10.14202/vetworld.2013.668-673.

[29] Sureshkumar V, Sarathchandra G \& Ramesh J (2013b), Veterinary pharmacovigilance evaluation on impact of enrofloxacin administration on antioxidant status in broiler chicken. International Journal of Current Microbiology and Applied Sciences 2, 335-341.

[30] Tietz NW (1995), Clinical guide to laboratory tests WB Saunders. Philadelphia, PA. 